\title{
Novel Molecular Mechanisms of Gangliosides in the Nervous System Elucidated by Genetic Engineering
}

\author{
Koichi Furukawa ${ }^{1,2, *(D)}$, Yuhsuke Ohmi ${ }^{3}$, Farhana Yesmin ${ }^{1,2}$, Orie Tajima ${ }^{1}$, Yuji Kondo ${ }^{2}{ }^{(0)}$, \\ Pu Zhang ${ }^{1,2}$, Noboru Hashimoto ${ }^{4}$, Yuki Ohkawa ${ }^{5}$, Robiul H. Bhuiyan ${ }^{1}$ and Keiko Furukawa ${ }^{1}$ \\ 1 Department of Biomedical Sciences, Chubu University College of Life and Health Sciences, 1200 Matsumoto, \\ Kasugai, Aichi 487-8501, Japan; farhana7779@gmail.com (F.Y.); oriet@isc.chubu.ac.jp (O.T.); \\ apor0825@yahoo.co.jp (P.Z.); biochemistrobi79@gmail.com (R.H.B.); keikofu@isc.chubu.ac.jp (K.F.) \\ 2 Department of Biochemistry II, Nagoya University Graduate School of Medicine, 65 Tsurumai, Showa-ku, \\ Nagoya 466-0065, Japan; Yuji-Kondo@omrf.org \\ 3 Department of Medical Technology, Chubu University College of Life and Health Sciences, 1200 Matsumoto, \\ Kasugai, Aichi 487-8501, Japan; ooumi82@isc.chubu.ac.jp \\ 4 Department of Tissue Regeneration, Tokushima University Graduate School of Biomedical Sciences, 3-18-5, \\ Kuramoto-cho, Tokushima 770-8504, Japan; nhashimoto@tokushima-u.ac.jp \\ 5 Department of Glycooncology, Osaka International Cancer Institute, Osaka 541-8567, Japan; \\ yuki34@mc.pref.osaka.jp \\ * Correspondence: koichi@isc.chubu.ac.jp; Tel./Fax: +81-568-51-9512
}

Received: 31 January 2020; Accepted: 6 March 2020; Published: 11 March 2020

check for updates

\begin{abstract}
Acidic glycosphingolipids, i.e., gangliosides, are predominantly and consistently expressed in nervous tissues of vertebrates at high levels. Therefore, they are considered to be involved in the development and function of nervous systems. Recent studies involving genetic engineering of glycosyltransferase genes have revealed novel aspects of the roles of gangliosides in the regulation of nervous tissues. In this review, novel findings regarding ganglioside functions and their modes of action elucidated mainly by studies of gene knockout mice are summarized. In particular, the roles of gangliosides in the regulation of lipid rafts to maintain the integrity of nervous systems are reported with a focus on the roles in the regulation of neuro-inflammation and neurodegeneration via complement systems. In addition, recent advances in studies of congenital neurological disorders due to genetic mutations of ganglioside synthase genes and also in the techniques for the analysis of ganglioside functions are introduced.
\end{abstract}

Keywords: ganglioside; knockout; neurodegeneration; glycosphingolipid; inflammation; microdomain

\section{Introduction}

Nervous tissues are differentiated from the ectoderm, and their morphology is determined before birth. During the growth stage after birth, further functional differentiation proceeds, and fundamental shapes and functions are established within several years in the case of humans. However, the formation of functional networks based on various experiences and learning activities proceed continuously, leading to the maintenance of high-grade nerve functions due to the plasticity of nervous systems [1]. After reaching middle age, the network function gradually declines along with aging, and physiological and pathological degeneration gradually proceed in nervous tissues [2]. Under certain pathological conditions, marked tissue degeneration is induced, leading to functionally irreversible states such as the occurrence of dementia. During individual processes in the natural history of nervous systems, structures of carbohydrates on proteins and lipids markedly alter [3] and are involved in the formation of appropriate environments for the high-grade structures and functions based on the molecular modification required for each step. 
Since acidic glycosphingolipids, i.e., gangliosides, are predominantly and consistently expressed in nervous tissues of vertebrates at high levels [3], their marked contribution to the neurological function has long been expected [4]. Actually, the fact that ganglioside expression patterns markedly change during development, suggests that they play critical roles in the evolution and differentiation of nervous systems $[5,6]$. Contrarily, for carbohydrates on proteins, sufficient understanding has been achieved in terms of integrative analysis of nervous system-specific carbohydrate functions, although there have been a number of reports on carbohydrate functions on individual proteins.

In this review, an outline of functions of gangliosides recently identified is summarized with a focus on findings from studies of knockout mice of various glycosyltransferase genes.

\section{Roles of Gangliosides}

Gangliosides are sialic acid-containing glycosphingolipids, which are widely expressed in almost all tissues and cells of vertebrates. They are enriched in brain tissues, suggesting that they are involved in the evolution and regulation of nervous systems [7]. The most intriguing feature of gangliosides is that they consist of hydrophilic carbohydrates and hydrophobic lipid portions [8], being expressed on the cell membrane and present in the outer layer of the lipid bilayer, as shown in Figure 1.

Therefore, it has remained unclear how gangliosides are involved in the regulation of signals for cell differentiation, activation, and malignant transformation [9]. This review summarizes ganglioside expression in inflammation and neurodegeneration and their roles in the maintenance of integrity and generation of phenotypes of cells with a focus on inflammation and degeneration due to the altered gangliosides are also summarized.

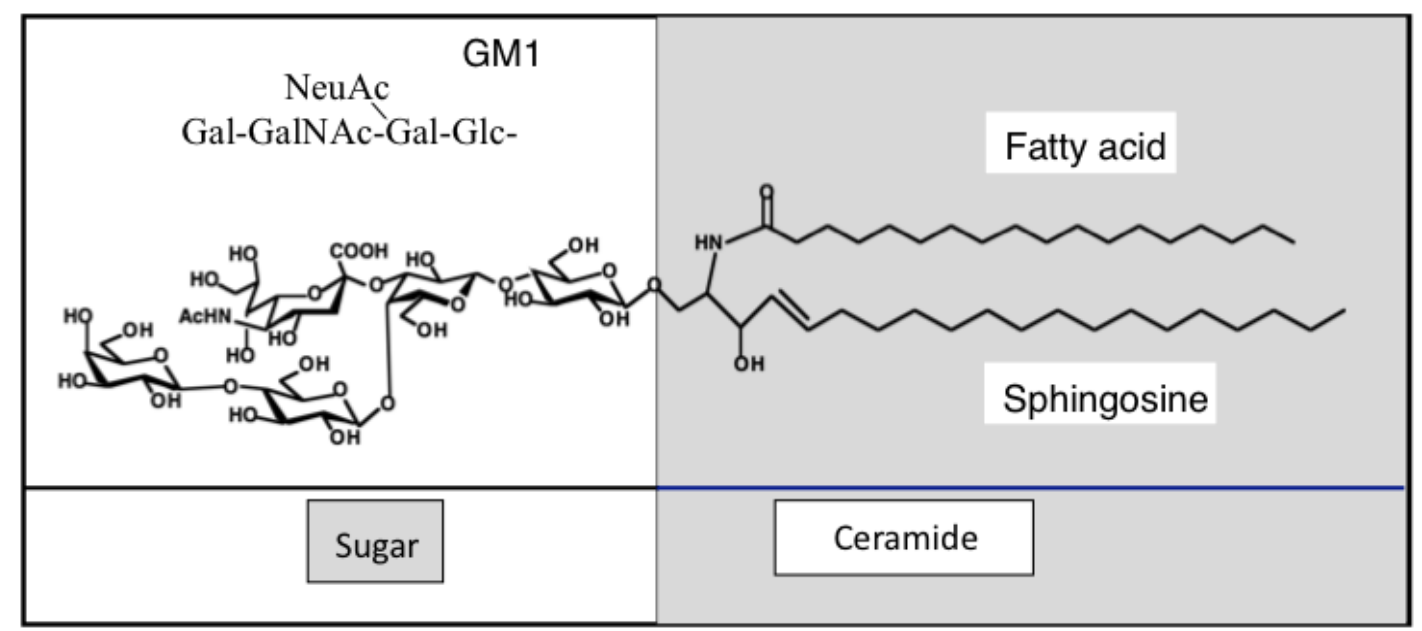

Figure 1. Glycosphingolipids are amphipathic molecules, expressed in the out layer of lipid two layers of the cell membrane. The hydrophobic portion (ceramide) is embedded in the outer layer of the membrane, and the sugar portion is protruding outside the membrane. A representative GM1 structure is shown. Ganglioside nomenclature is according to Svennerholm [10].

\subsection{Gangliosides in Development and Growth}

The fact that ganglioside composition in brain tissues varies along with development and growth of organisms has been well reported [7,11]. It is also well understood that simple structure gangliosides such as GM3 and GD3 mainly exist at the initial stage of development, i.e., embryonal day 12 to 14 (E12-14) of mice. At the differentiation stage after E16, when extension of neurites and synapse formation occur, mature-type gangliosides such as GM1, GD1a, GD1b, and GT1b increase and become the main components of brain tissues [12]. The main pathway of ganglioside synthesis is shown in Figure 2. Generally, a-series and b-series gangliosides are major structures in brain tissues, and minimal levels of c-series and asialo-series are sometimes detected. In particular, complex gangliosides containing extended core structures higher than GM1 and GD1b are frequently expressed in brain 
tissues after the late developmental stage, and sometimes affect pathological conditions such as Alzheimer's disease, as described below.

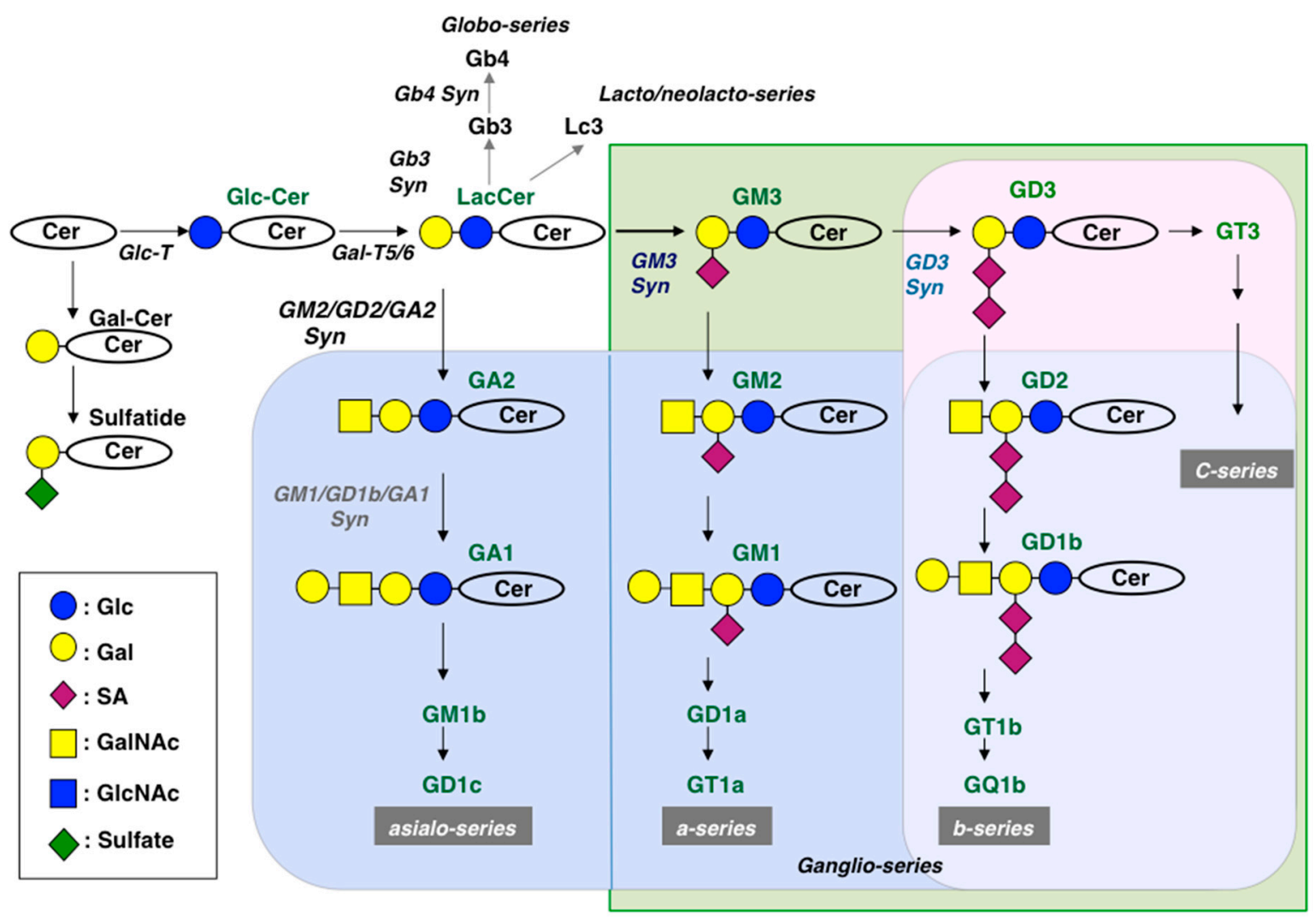

Figure 2. Main pathway of ganglioside synthesis. Glycosyltransferases catalyzing individual steps are shown by italics, and deleted structures in $\mathrm{KO}$ mice are shown by different colored squares. Structures on the line of ganglioside synthesis are presented in green letters.

Differently, the ganglioside composition in brain tissues shows almost no change in the adult stage, while total amounts gradually reduce. In particular sites of the brain, however, gradual changes occur along with aging [7]. Only a few comprehensive studies on ganglioside expression in nerve tissues have been performed to date $[13,14]$.

\subsection{Function of Monosialylgangliosides and Disialylgangliosides}

In order to analyze the regulatory function of nervous systems by gangliosides, a rat pheochromocytoma cell line, PC12, has been frequently used $[15,16]$. On the one hand, PC12 cells overexpressing GM1 showed reduced sensitivity to the nerve growth factor (NGF), leading to lowered neurite extension, and exhibited suppressed activation of TrkA/Ras/ERK1/2 signals upon NGF stimulation [17]. On the other hand, GD3-overexpressing PC12 cells showed increased phosphorylation levels of TrkA and ERK1/2 even without NGF stimulation [18]. Similarly, contrastive effects of gene expression between GM1 synthase and GD3 synthase on phenotypes of various cancer cell lines have been observed $[19,20]$. From these results, it has been demonstrated that monosialylgangliosides and disialylgangliosides play distinct roles in the regulation of malignant properties of cancer cells [9].

Although mechanisms for signal regulation in cancer cells and PC12 cells based on gangliosides with different numbers of sialic acids remain unclear, it could be a reflection of regulatory functions of gangliosides in organogenesis and differentiation of nervous tissues and cells. Dynamic changes in ganglioside expression during the evolution and development of nervous tissues and their implications are summarized in the next chapter. 


\section{Aging, Neurodegeneration, and Gangliosides}

In various tissues and cells, only nervous tissues have been thought to show consistent compositions among species of mammals and birds. In fact, very similar thin-layer chromatography (TLC) patterns of gangliosides extracted from brain tissues were reported [21]. However, various changes in ganglioside composition under physiological and pathological conditions have been investigated $[2,8,22]$.

\subsection{Changes of Gangliosides in Central Nervous Systems with Aging}

There have been some reports on the changes of ganglioside expression during evolution, development, and aging of mice and rats [23-25]. For human brain gangliosides, changes of ganglioside expression have been reported. Generally, contents of gangliosides gradually decrease [26], and, on the one hand, a-series gangliosides tend to decrease mainly in the frontal cortex [27]. On the other hand, b-series gangliosides decrease in the cerebellum with aging. Total amounts of lipids contained in brain tissues continuously reduce until reaching 90 years old. In particular, expression levels of gangliosides and cerebrosides are largely lowered at that time point. Investigation of 118 individuals aged 20 to approximately 100 years old revealed that concentrations of gangliosides were maintained between 20 and approximately 70 years old [28], and then the expression patterns continuously altered with aging, leading to reduced ratios of GM1 and GD1a. Similar findings were reported based on the newest analytical techniques using mass spectrometry [29]. However, there has been no detailed research on the functional relationship of altered ganglioside expression with pathological changes in brain tissues.

\subsection{Gangliosides in Alzheimer's Disease}

In a variety of neurodegenerative diseases, particularly Alzheimer's disease, one of the most important factors involved in neuron death is local inflammation [30]. As reported previously, all components involved in the classic pathway of complement activation were detected in nervous tissues, and this pathway is activated in Alzheimer's disease, resulting in detection as fibrous $\beta$ amyloid [30] or neurofibrillary tangles [31]. From these findings, complement activation and subsequent inflammation can be the main mechanisms for the induction of brain damage in Alzheimer's disease.

Over approximately the last 20 to 30 years, it has been demonstrated that the complement system is involved in neurodegeneration such as in Alzheimer's disease [32]. C1q and other components deposit in amyloid plaques and neurofibrillary tangles [33,34], leading to complement activation. In areas with legions, levels of mRNAs for complement components markedly increased [35]. Furthermore, C1q inhibitors alleviated clinical features of Alzheimer's disease, suggesting that complement activation plays important roles in neuroinflammation and subsequent neurodegeneration [36]. Interestingly, the complement activation observed in double knockout (DKO) mice (deleting GM2/GD2 synthase and GD3 synthase) containing only GM3 plays similar roles to those in Alzheimer's disease. This point will be described later.

Furthermore, complement systems can have both detrimental and beneficial effects regarding disease control [37]. For example, roles during developmental processes [38] or neuronal generation in adults [39] have been reported. In particular, its physiological roles in the elimination of unnecessary cellular components or in the improvement of inflammatory reaction are of interest.

As a role of gangliosides in Alzheimer's disease, GM1 has been reported to be a factor triggering the aggregation of $A \beta$ peptides on the cell membrane [40], and mechanisms leading to the continuous accumulation of $A \beta$ have also been proposed [41]. Murine models of Alzheimer's disease generated with genetic backgrounds of knockout of the GD3 synthase gene or GM2/GD2 synthase gene have been generated, resulting in milder phenotypes in the former [42], and more serious phenotypes in the latter [43]. Recently, it was reported that the expression of B4GALNT1 promoted the processing of $\mathrm{A} \beta$ [44], and complex gangliosides exacerbated clinical features of Alzheimer's disease. Additionally, different changes in ganglioside composition were found in various transgenic model mice expressing 
human amyloid precursor proteins. [45]. From these results, it has been suggested that altered metabolism of gangliosides is involved in the pathogenesis of Alzheimer's disease.

\subsection{Parkinson Disease and Gangliosides}

It has been reported that the amounts of GM1 and GD1a are reduced in the brains of patients with Parkinson disease [46]. Furthermore, it was also indicated that B4galnt1 (GM2 synthase) KO mice lacking GM1 ganglioside [47] showed Parkinson disease-like neurological disorders even in heterozygotes [48]. Indeed, the efficiency of GM1 administration to Parkinson disease model animals has been reported [49], and similar trials have also been performed in clinical cases, resulting in the improvement of clinical features [50]. For example, GD3 synthase9 (ST8SIA1) KO mice lacking b-series gangliosides and showing increased levels of GM1 and GD1a [51] were reported to be less susceptible to Parkinson disease [52], suggesting that supplementation of GM1 or GD1a is also effective for patients with other neurodegenerative diseases [46].

\subsection{Inflammatory Reaction and Gangliosides}

Changes in ganglioside expression in various inflammatory reactions have been observed to date [53]. For example, changes in gangliosides expressed on glial cells [54] or in multiple sclerosis, or changes by growth factors [55] have been reported. Furthermore, it has been reported that the ganglioside GD3 was induced in inflammatory environments of brain tissues in mice and rats [56]. Regarding immune cells, GD3/GD2 were induced in T lymphocytes when stimulated via T-cell receptors or IL-2 receptors, or various mitogenic factors [57,58]. Moreover, ganglioside GD2 was expressed on functional T cells [59]. These results are consistent with a report that GD2 was induced on HTLV-1-infected T cells via a viral product, p40tax [60]. Thus, changes in ganglioside expression patterns on immune cells are frequently observed in various inflammatory reactions [61,62].

\section{Functions of Glycolipids Elucidated in Ganglioside-Deficient (Knockout) Mice}

\subsection{Abnormal Phenotypes Exhibited by Knockout Mice and Inflammatory Reaction}

In order to investigate roles of glycosphingolipids, cDNAs of various glycosyltransferase genes have been isolated, i.e., GM2/GD2 synthase [63], GD3 synthase [64-66], GM1/GD1b/GA1 synthase [67], GM3 synthase [68-70], Gb3 synthase [71-73], and many other glycosyltransferase cDNAs, and then knockout $(\mathrm{KO})$ mouse lines of these enzyme genes have been established. For example, $\mathrm{KO}$ mouse lines of GM2/GD2 synthase [47], GD3 synthase [51], Gb3 synthase [74], lactosylceramide (LacCer) synthase [75,76], and double KO mice of GM2/GD2 synthase and GD3 synthase $[77,78]$ have been established and analyzed. DKO mice of B6galt5 and B4galt6 were also generated [79]. Synthetic pathways of the main glycosphingolipids and glycolipid structures deleted in individual $\mathrm{KO}$ mice are presented in Figure 2. Generally, abnormal phenotypes observed in these $\mathrm{KO}$ mouse lines were milder than expected. This could be because residual glycolipids compensate for the functions of deleted structures [47]. All these results are summarized in Table 1. However, it is interesting that inflammatory reactions were found mainly in the central nervous systems of many of these $\mathrm{KO}$ mice involving glycosyltransferase genes [80]. Biochemical and morphological changes observed in the DKO mice of GM2/GD2 synthase and GD3 synthase genes were also detected in many single gene KO mouse lines [81] (Table 1).

We reported the involvement of complement systems in neuro-inflammation as a novel aspect of ganglioside deficiency [80]. We compared the degree of complement activation, inflammatory reaction, and destruction of lipid rafts among various $\mathrm{KO}$ mice of glycosyltransferase genes and wild type (WT) mice and demonstrated extensively increased expression levels of complement-related genes. Moreover, we reported the proliferation of astrocytes and assembly of microglia corresponding to the degree of defects in ganglioside composition in individual $\mathrm{KO}$ mice (Figure 3). It was also shown that various cytokine genes were upregulated with aging, corresponding with the progression of 
neuro-inflammation, as described above. The molecular mechanisms of this inflammation based on ganglioside deficiency were analyzed with a focus on changes in lipid rafts [81]. Details are described in the Section 5.

Table 1. Deficient structures, remaining glycolipids, and phenotypes of individual KO mice of glycosyltransferase genes. Residual glycolipids could compensate for the functions that deleted structures primarily exerted.

\begin{tabular}{|c|c|c|c|c|c|}
\hline KO Gene & Glc-Cer Syn & GM3 Syn & GD3 Syn & GM2/GD2 Syn & $\mathrm{DKO}^{1)}$ \\
\hline Lost structures & $\begin{array}{l}\text { all glyco- } \\
\text { sphingolipids }\end{array}$ & $\begin{array}{l}\text { ganglio-series } \\
(\mathrm{a}-, \mathrm{b}-, \mathrm{c}-)\end{array}$ & $\begin{array}{c}\text { b-series } \\
\text { (and c-series) }\end{array}$ & $\begin{array}{l}\text { all complex } \\
\text { gangliosides(inc. } \\
\text { asialo-series) }\end{array}$ & $\begin{array}{l}\text { all complex } \\
\text { gangliosides(inc. } \\
\text { asialo-series) }\end{array}$ \\
\hline \multirow[t]{2}{*}{$\begin{array}{l}\text { Remaining } \\
\text { structures }\end{array}$} & & asialo-series & $\begin{array}{l}\text { a-series and } \\
\text { asialo-series }\end{array}$ & GM3, GD3 (and GT3) & GM3 \\
\hline & $\begin{array}{l}\text { Gal-Cer and } \\
\text { sulfatedes }\end{array}$ & $\begin{array}{c}\text { Gal-Cer and } \\
\text { sulfatedes } \\
\text { neutral glycolipids }\end{array}$ & $\begin{array}{c}\text { Gal-Cer and } \\
\text { sulfatedes } \\
\text { neutral glycolipids }\end{array}$ & $\begin{array}{c}\text { Gal-Cer and } \\
\text { sulfatedes } \\
\text { neutral glycolipids }\end{array}$ & $\begin{array}{l}\text { Gal-Cer and sulfatedes } \\
\text { neutral glycolipids }\end{array}$ \\
\hline \multirow[t]{2}{*}{ Phenotypes } & $\downarrow$ & $\downarrow$ & $\downarrow$ & $\downarrow$ & $\downarrow$ \\
\hline & $\begin{array}{l}\text { Embryonal } \\
\text { lethal }\end{array}$ & $\begin{array}{l}\text { No apparent } \\
\text { abnormalities }\end{array}$ & Mild abnormalities & $\begin{array}{c}\text { Gradual } \\
\text { abnormalities }\end{array}$ & $\begin{array}{l}\text { Neurodegeneration } \\
\text { from early phase }\end{array}$ \\
\hline Remarks & & Auditory disorder & $\begin{array}{l}\text { Poor repair Low } \\
\text { serum leptin }\end{array}$ & $\begin{array}{l}\text { Male infertileity Low } \\
\text { serum testostelone } \\
\text { Wallerian degen }{ }^{2}\end{array}$ & $\begin{array}{l}\text { Refractory skin lesion } \\
\text { Auditory shock }\end{array}$ \\
\hline
\end{tabular}

${ }^{1)}$, double $\mathrm{KO}$ of GD3 synthase and GM2/GD2 synthase genes; ${ }^{2}$, Wallerian degeneration.

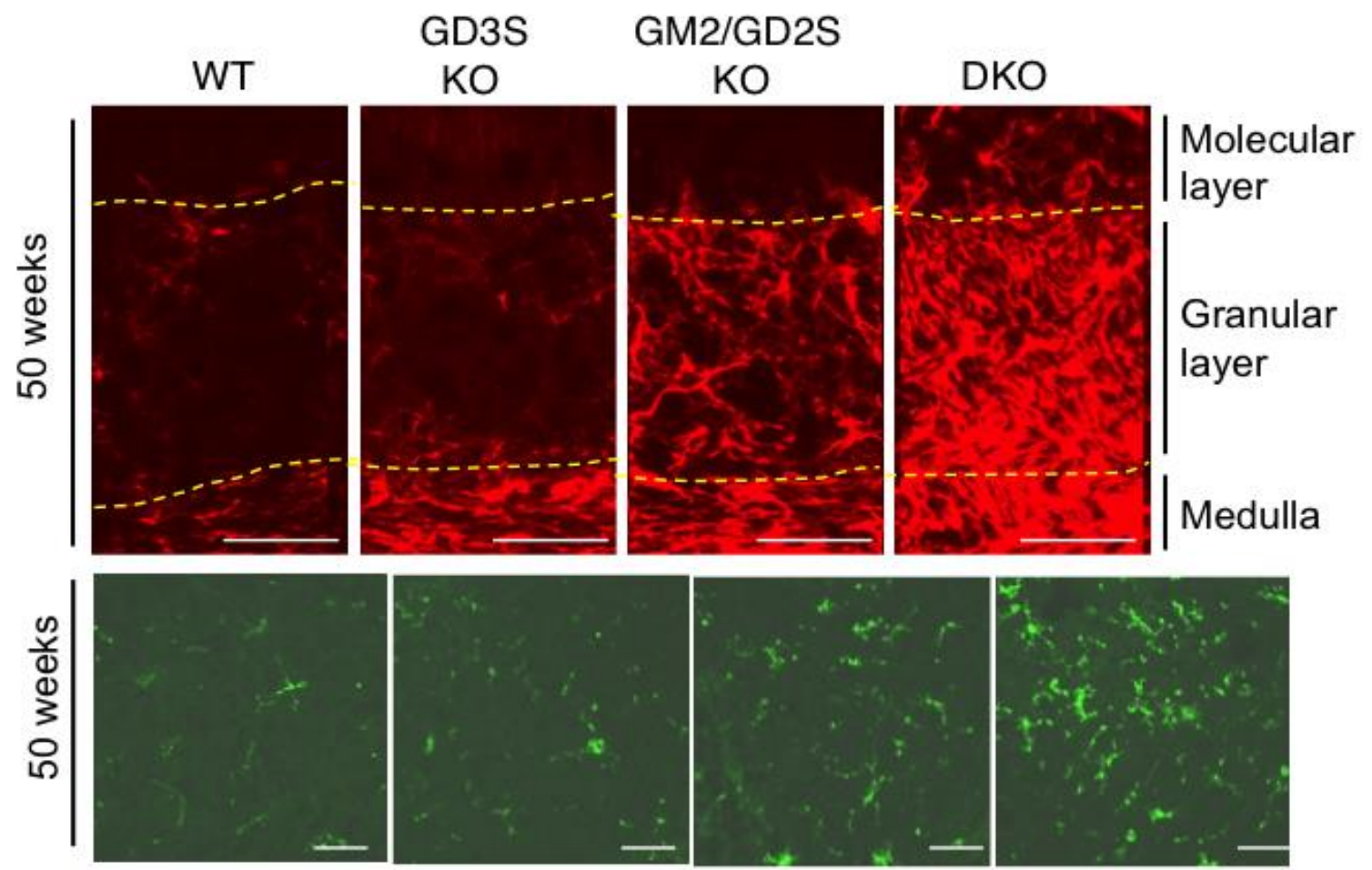

Figure 3. Immunohistochemistry of GFAP-positive astrocytes and F4/80-positive microglia. Cerebella from 50-week-old mice were analyzed by anti-glial fibrillary acidic protein (GFAP) antibody and Alexa Fluor 555-conjugated anti-mouse IgG1, and anti-mouse F4/80 and Alexa Fluor 488-conjugated anti-rat IgG. Marked gliosis was found in ganglioside synthase gene KO mice. GFAP-positive cells were increased (upper, red), and F4/80-positive cells (lower, green) accumulated in cerebella, indicating astrocytes and microglia, respectively. Scale bar, $50 \mu \mathrm{m}$ in both panels. Borders between layers of the cerebellum indicated based on Hematoxylin-Eosin staining of serial sections. 


\subsection{Neuro-Inflammation Corresponding to the Degree of Ganglioside Deficiency}

Gangliosides have been considered to be involved in the development, differentiation, and function of nervous systems [82]. However, gangliosides have been shown to play roles mainly in the maintenance and repair of nervous tissues based on the abnormal phenotypes detected in genetically engineered mutant mice [83].

Generally, neurodegeneration was commonly found in $\mathrm{KO}$ mouse lines of ganglioside synthase genes $[47,84,85]$. In particular, age-dependent progressive neurodegeneration was observed in $\mathrm{KO}$ mice of GM2/GD2 synthase, while subtle abnormal neurological signs could be detected when they were born [47]. In addition, DKO mice of GM2/GD2 synthase and GD3 synthase genes demonstrated neurodegeneration in the early stage of life [77], or even sudden death by auditory stimulation [86]. Although KO mice lacking GlcCer synthase [87] showed embryonal lethality [88], conditional KO mice in which GlcCer synthase was deleted after birth also showed neurodegeneration [36]. These results indicate that ganglioside deficiency causes abnormality in the maintenance of integrity of the nervous system, leading to neurodegeneration. However, it remains unclear how ganglioside deficiency causes neurodegeneration.

Among various features indicating inflammation in the nervous tissues, abnormal proliferation of astrocytes and assembly of microglia were markedly and characteristically found in the cerebella of ganglioside deficient mice [80]. Furthermore, these inflammatory reactions were confirmed by immunohistochemistry, such as GFAP-positive astrocytes and F4/80 antibody-reactive microglia (Figure 3). GFAP+ cells increased at 15 weeks after birth in DKO mice, and further increased with aging. At 50 weeks after birth, GFAP+ cells increased even in single gene $\mathrm{KO}$ mice, such as GD3 synthase $\mathrm{KO}$ or GM2/GD2 synthase KO. Microglia cells also showed increased assembly at 15 weeks after birth in DKO mice, and further increased with aging. This microglia assembly could also be found at 50 weeks after birth in single gene KO mice [80].

As for inflammatory cytokines, increased expression levels of IL-1 $\beta$ and TNF $\alpha$ genes were detected in RT-PCR of mRNA from the cerebella of DKO mice. Expression levels of these genes tended to increase with aging in DKO mice, while no apparent changes in those gene expression could be found in WT or single gene $\mathrm{KO}$ mice.

\subsection{Involvement of Complement System in the Inflammatory Reaction}

From the results of gene expression analysis in DKO mice, it was demonstrated that complement-related genes were generally upregulated in the cerebella of DKO mice. Therefore, it was suggested that wide-ranging consumption of complement components was induced due to activation of the complement system [80]. Actually, the deposition of C1q, a complement component, could be found in the cerebella of DKO mice, and it was also the case in KO mice of GM2/GD2 synthase. [80]. In order to investigate whether complement activation detected in the cerebella of DKO mice exacerbates with aging, expression levels of $\mathrm{C} 1 \mathrm{q} \alpha, \mathrm{C} 3$, and $\mathrm{C} 4$ were examined along with aging, resulting in increased expression of the $\mathrm{C} 1 \mathrm{q}$ gene between 15 weeks to 50 weeks after birth, and in differences from WT mice with aging. In GM2/GD2 synthase KO mice, expression of complement-related genes moderately increased. Similar inflammatory reactions were also observed in spinal cords of these KO mice [89].

To clarify the roles of complement activation in neuro-inflammation and neurodegeneration, triple $\mathrm{KO}$ mice lacking the complement $\mathrm{C} 3$ gene, as well as GM2/GD2 synthase and GD3 synthase genes, were established as shown in Figure 4 [83]. In these TKO mice, it was shown that complement activation is involved in complement deposition and secretion of inflammatory cytokines and also in neurodegeneration, as demonstrated by the alleviation of brain degeneration indicated by a reduction in brain weights. In neurological disorders such as Guillan-Barre syndrome and Miller syndrome caused by anti-ganglioside antibodies, it has been reported that complement systems are closely involved $[90,91]$. Therefore, inhibitors of complement-related components have undergone therapeutic 
application for the control of these diseases, showing beneficial effects in mouse disease models [92] and human cases [93].

A

Generation of triple KO mice

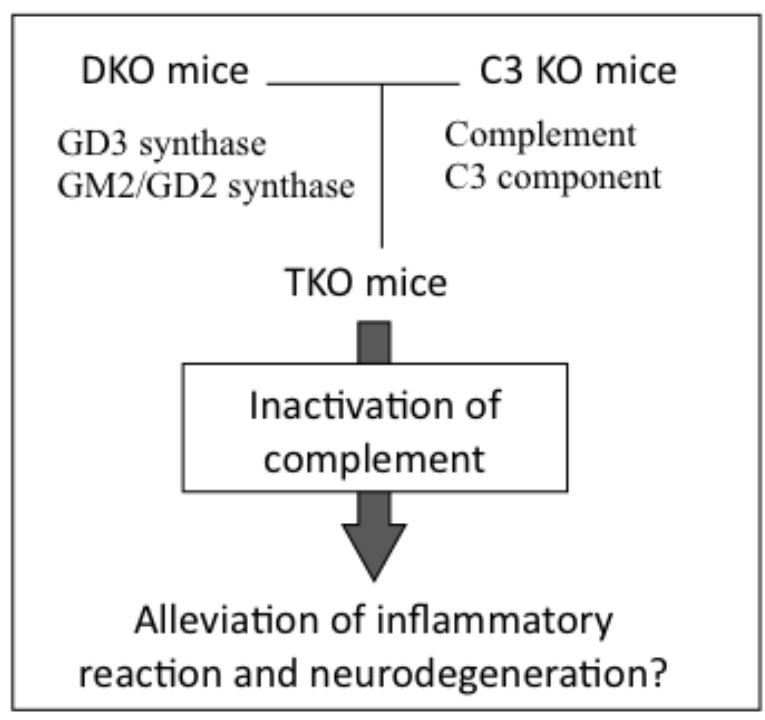

B
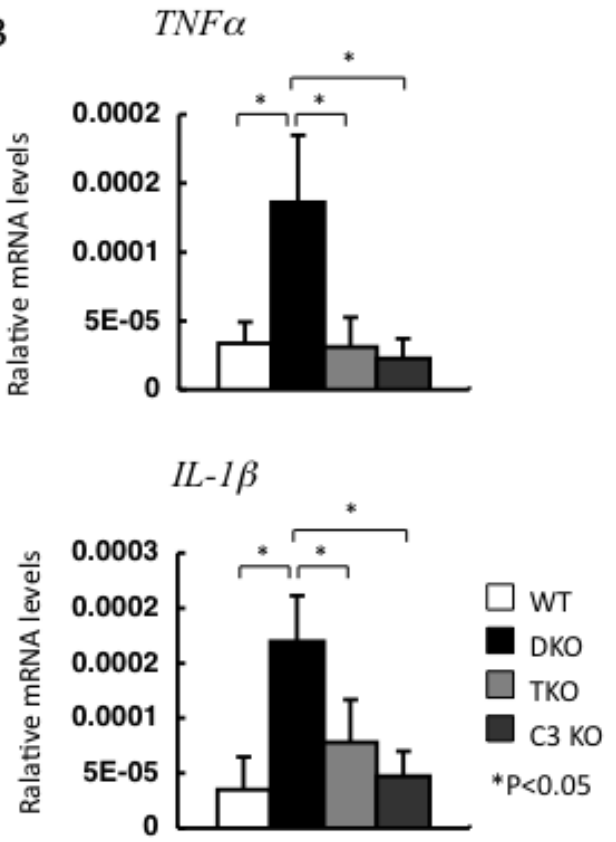

Figure 4. Inflammatory reactions in DKO mice were suppressed by genetic disruption of complement system. (A) Triple KO (TKO) mice were generated by mating DKO mice with C3 KO mice to clarify the roles of complement systems in brain disorders in DKO mice. (B) Expression levels of inflammatory cytokines were reduced in TKO mice. Relative mRNA levels of TNF $\alpha$ and $I L-1 \beta$ were compared using RT-qPCR.

\section{Microdomains on Cell Membrane and Gangliosides}

Generally speaking, membrane microdomains such as lipid rafts, glycolipid-enriched microdomain (GEM)/rafts, or detergent-insoluble microdomains (DIM) are considered to be a platform of cell signaling, and roles of glycosphingolipids in lipid rafts have been increasingly recognized [94]. In particular, the molecular composition of gangliosides that consist of polymorphic sugar chains and heterogenous lipid moieties has led to the expectation that gangliosides could be one of the main regulators of biological properties of microdomains.

\subsection{Gangliosides Regulate Cell Signaling in Microdomains}

Various extrinsic stimulations are transduced via receptors and their adjacent molecules on the cell membrane, and these molecules often form molecular complexes in microdomains, such as lipid rafts or GEM/rafts [9,95] (Figure 5). With a number of experiments using cell lines and KO mice, it has been shown that changes in ganglioside expression largely affect lipid rafts and control the cell signals, and finally cellular phenotypes [94]. Therefore, the integrity of lipid rafts has been investigated by analyzing changes in the intracellular localization of membrane molecules depending on the conditions of glycosphingolipids and cells $[96,97]$. Immunocytostaining of these membrane molecules has been an efficient approach for the localization of the same membrane microdomains. Furthermore, it seems extremely important to substantially reveal physical interactions among these molecules on the living cell membrane, which would become a prerequisite to clarify the roles of gangliosides and their associated molecules on the cell membrane [98]. 
WT

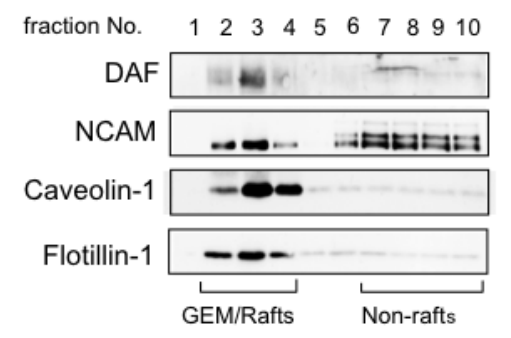

GD3S KO

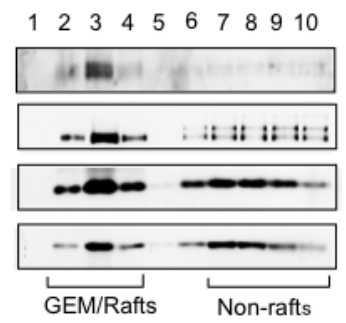

GM2/GD2S KO

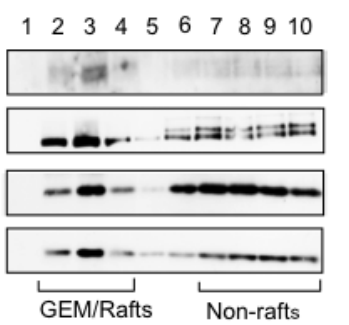

DKO

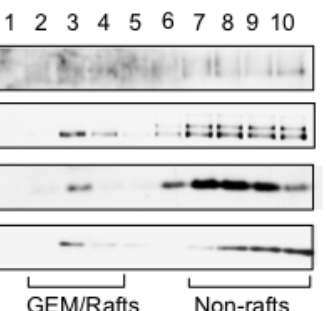

GPIanchored proteins (DAF, CD59)

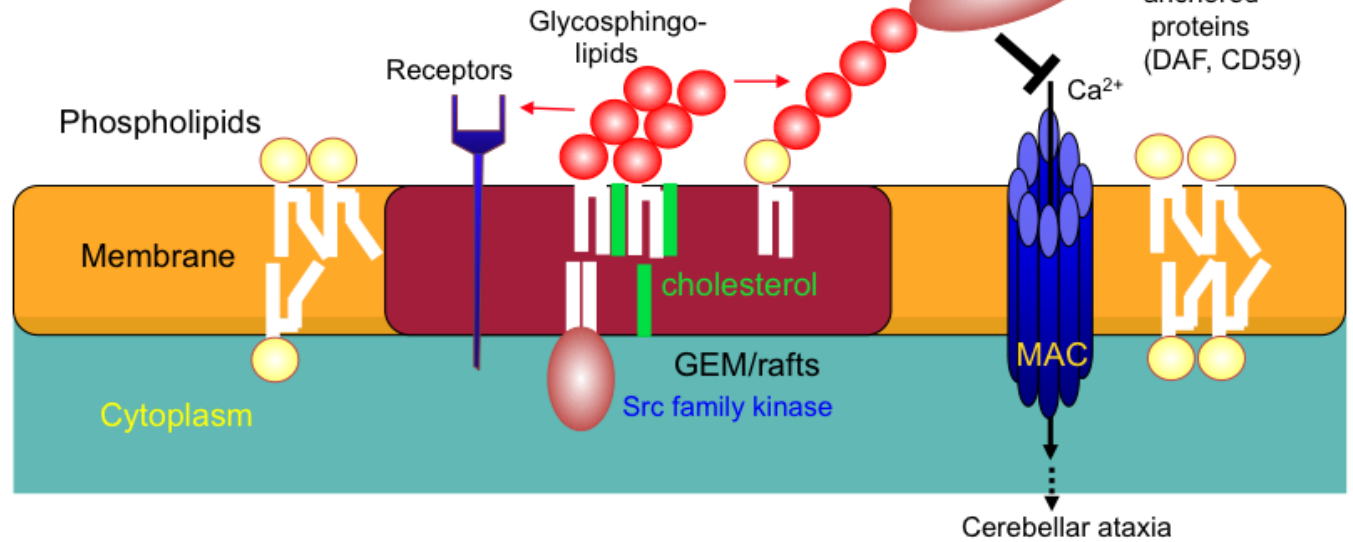

Figure 5. Destruction of the GEM/raft induced changes in the architecture and functions of raft-localizing molecules. Localization of GPI-anchored proteins including complement-regulatory molecules changed, leading to functional abnormalities and subsequent complement activation and inflammation in ganglioside-deficient mouse brain. GPI-anchored molecules such as DAF and NCAM as well as GEM/raft markers shifted from GEM/rafts to non-rafts domains. A part of a figure in Ref. 81 was presented after modification. Among isoforms of NCAM, only the GPI-anchored one was detected in GEM/rafts.

\subsection{Microdomain on the Cell Membrane of Nervous Systems and Gangliosides}

Glycosphingolipids are generally considered to be concentrated and localized in GEM/rafts [99], and intense localization is found in highly differentiated neurons. However, they are dispersed from lipid rafts in particular environments [100]. In addition, changes in relevant molecules such as caveolin-1 affect the intracellular localization of glycosphingolipids [101]. Furthermore, fine distribution analysis of gangliosides using immunoelectron microscopy revealed that different ganglioside species (e.g., GM1 and GM3) showed distinct distribution patterns on the cell membrane, suggesting the presence of heterogeneous microdomains, and that individual gangliosides form specific microdomains [102].

Surprisingly, GPI-anchored proteins and GEM/raft markers dispersed from GEM/rafts in the cerebella of ganglioside-deficient mice, and marked cell damage was induced $[80,81,103]$. Analysis of altered floating patterns of GPI-anchored proteins and GEM/rafts markers in various ganglioside-deficient mouse lines by immunoblotting revealed that flotillin- 1 and caveolin- 1 were dispersed from GEM/rafts (Figure 5). DAF and NCAM showed marked dispersion from GEM/rafts in DKO mice, and DAF shifted to the non-GEM/raft fraction in GM2/GD2 synthase KO mice. Total protein amounts showed no differences among these lines. Generally, gangliosides are essential in the architecture of GEM/rafts, and it is suggested that more marked abnormalities of GEM/rafts are exhibited in DKO mice than in single gene $\mathrm{KO}$ mice.

\subsection{Complement Activation and Destruction of Lipid Rafts}

The results of the analysis of DKO mice revealed that there were many examples of molecular dispersion of GPI-anchored proteins and GEM/raft markers even in single gene $\mathrm{KO}$ mice, suggesting 
that disordered GEM/rafts in brain tissues induce dysfunction of GPI-anchored proteins. In GM2/GD2 synthase gene $\mathrm{KO}$ and DKO mice, localization of GalCer, phospholipids, and cholesterol tended to decrease [81], suggesting that the abnormal composition of gangliosides could induce abnormal distribution patterns of GPI-anchored proteins and raft marker proteins, and also of other lipids.

One of the most important factors involved in the complement activation and resulting neurological disorders should be complement-regulatory proteins. In fact, it is well known that expression levels of CD59 are lower at the sites of Alzheimer's disease [104]. DAF is also a crucial molecule for the maintenance of tissue integrity [105]. Many of these complement-regulatory factors belong to GPI-anchored proteins and are concentrated in the GEM/raft fraction [106]. Therefore, it is suggested that destruction of the GEM/raft induced changes in the localization of GPI-anchored proteins and their functional abnormalities, leading to complement activation and inflammation. These processes are summarized in Figure 5.

\section{Human Diseases Caused by Congenital Deficiency of Gangliosides}

Following the analysis of ganglioside functions using $\mathrm{KO}$ mice of glycosyltransferase genes, human cases of congenital defects of ganglioside synthase genes have been reported in this century.

\subsection{GM3 Synthase Deficiency Causes Severe Clinical Features}

Although there have been a number of studies on deficiency of ganglioside catalytic enzyme genes, no reports on congenital deficiency of ganglioside synthase genes were published until 2004. Simpson et al. reported "infantile epilepsy" in Amish families due to deficiency of GM3 synthase (ST3GAL5) as the first case of genetic mutation in ganglioside synthase genes [107].

As described above, the majority of gangliosides are synthesized through GM3, and diverse carbohydrate structures are generated from a common precursor, lactosylceramide, along with several major synthetic pathways [25]. Therefore, defects of the GM3 synthase gene in the Amish families actually resulted in the complete loss of ganglio series and the patients exhibited serious infantile epileptic disorders [107] and skin abnormalities [108,109], suggesting that gangliosides are essential in the regulation of nervous tissues and other organs. Thus, patients lacking GM3 synthase activity exhibited severe neurological disorders such as infantile epilepsy, mental retardation, visual disorders, and also skin pigmentation abnormalities, while no definite abnormal phenotypes were found in $\mathrm{KO}$ mice of the GM3 synthase gene (St3gal5) in any sites of the body except for the auditory system [110].

\subsection{GM2/GD2 Synthase Gene Deficiency Causes Hereditary Spastic Paraplegia}

B4GALNT1 is an essential enzyme for the synthesis of complex gangliosides, the lack of which resulted in progressive neurodegeneration with aging in mice [84]. Recently, 11 cases of hereditary spastic paraplegia (HSP) due to mutation in the coding region of B4GALNT1 were reported [111-113]. We examined the enzyme activities using a cell-free enzyme assay with cell extracts, and by flow cytometry of transfected cells with mutant cDNA expression plasmids [114]. Among them, almost all mutant genes showed the complete loss of B4GALNT1 activity, while two mutants showed low activity, indicating that the clinical findings of these patients were derived from the loss of B4GALNT1 enzyme activity, and that mutations were responsible for the clinical features of HSP. As expected from $\mathrm{KO}$ mice phenotypes of the B4galnt1 gene, the intensity of their neurological disorders was milder than expected. These clinical features of patients including male hypogonadism are very similar to the abnormal phenotypes detected in B4galnt1-deficient mice [115]. In contrast to GM3 synthase mutation, B4GALNT1 mutations brought about much milder clinical features with slower progression.

\section{Future Scope of Ganglioside Research}

Recent advances in methodologies and technologies have enabled us to further investigate modes of action of gangliosides. Fine heterogeneity in either the sugar moiety or ceramide portion has been demonstrated, leading to further understanding of the mechanisms by which gangliosides play their 
roles or interact with their recognizing molecules. For example, further analysis of derivatives of sialic acids such as deaminoneuraminic acid (KDN) [116], O-acetylated GD3/GD2 [117] as sugar modifications, and long fatty chain-containing glycolipids in lactosylceramide [118], saturated/unsaturated fatty acid-containing Gb4 [119], or hydroxylated ceramide-containing gangliosides [120], remain to be promoted. It is also important to identify the cell lineages that more critically need gangliosides between neurons and glia [121], although few studies have been reported to date. Ultrahigh-resolution imaging of gangliosides in GEM/rafts has enabled us to understand the actual formation of microdomains [122] and to generate new concepts regarding the gradual formation of GEM/rafts with different sizes and compositions [123]. Identification of novel ligand molecules for gangliosides should also be promoted to further understand the molecular functions of gangliosides [98], although few studies in the neurology field have been reported to date.

\section{Conclusions}

It is difficult to clearly answer the fundamental question, i.e., "What are the roles of gangliosides in nerve functions?" Many of the "functions" presented here are results drawn from observation of abnormal situations brought about by artificially enhanced expression of particular glycosyltransferases or suppression of their functions to speculate on the normal functions primarily exerted. Therefore, they represent a part of "functions", but not all. The main limiting factor is the technical restriction in the manipulation of key glycosyltransferase genes, observing some phenotypes as functions of many structures belonging to one group all together. However, clarification of the roles of individual gangliosides by collecting experimental data with various limitations is essential to understand the polymorphism of carbohydrates.

Funding: This research was funded by the Grants-in-Aid from the Ministry of Education, Culture, Sports and Technology of Japan (MEXT) 18H02628, 17K19616, 19K22518, 23110008, and by a grant from Yokoyama Rinsho Yakuri Foundation.

Conflicts of Interest: The authors declare no conflict of interest.

\section{References}

1. Batool, S.; Hussain Raza, H.; Zaidi, J.; Riaz, S.; Hasan, S.; Syed, N.I. Synapse Formation: From Cellular and Molecular Mechanisms to Neurodevelopmental and Neurodegenerative Disorders. J. Neurophysiol. 2019, 121, 1381-1397. [CrossRef]

2. Ando, S. Neuronal dysfunction with aging and its amelioration. Proc. Jpn. Acad. Ser. B Phys. Biol. Sci. 2012, 88, 266-282. [CrossRef]

3. Moll, T.; Shaw, P.J.; Cooper-Knock, J. Disrupted glycosylation of lipids and proteins is a cause of neurodegeneration. Brain 2019. [CrossRef]

4. Yu, R.K.; Tsai, Y.T.; Ariga, T. Functional roles of gangliosides in neurodevelopment: An overview of recent advances. Neurochem. Res. 2012, 37, 1230-1244. [CrossRef]

5. Itokazu, Y.; Wang, J.; Yu, R.K. Gangliosides in nerve cell specification. Prog. Mol. Biol. Transl. Sci. 2018, 156, 241-263.

6. Maccioni, H.J.; Quiroga, R.; Ferrari, M.L. Cellular and molecular biology of glycosphingolipid glycosylation. J. Neurochem. 2011, 117, 589-602. [CrossRef]

7. Schnaar, R.L. The Biology of gangliosides. Adv. Carbohydr. Chem. Biochem. 2019, 76, 113-148.

8. Sonnino, S.; Chiricozzi, E.; Grassi, S.; Mauri, L.; Prioni, S.; Prinetti, A. Gangliosides in membrane organization. Prog. Mol. Biol. Transl. Sci. 2018, 156, 83-120. [PubMed]

9. Furukawa, K.; Ohkawa, Y.; Yamauchi, Y.; Hamamura, K.; Ohmi, Y.; Furukawa, K. Fine tuning of cell signals by glycosylation. J. Biochem. 2012, 151, 573-578. [CrossRef] [PubMed]

10. Svennerholm, L. Chromatographic separateion of human brain gangliosides. J. Neurochem. 1963, 10, 613-623. [CrossRef] [PubMed]

11. Schengrund, C.L. Gangliosides: Glycosphingolipids essential for normal neural development and function. Trends Biochem. Sci. 2015, 40, 397-406. [CrossRef] [PubMed] 
12. Yu, R.K.; Macala, L.J.; Taki, T.; Weinfield, H.M.; Yu, F.S. Developmental changes in ganglioside composition and synthesis in embryonic rat brain. J. Neurochem. 1988, 50, 1825-1829. [CrossRef] [PubMed]

13. Suzaki, K. The pattern of mammalian brain gangliosides. 3. Regional and developmental differences. J. Neurochem. 1965, 12, 969-979. [CrossRef] [PubMed]

14. Vrbaski, S.R. Cerebellum gangliosides in postnatal rats. J. Neurochem. 1980, 34, 1032-1033. [CrossRef] [PubMed]

15. Greene, L.A.; Tischler, A.S. Establishment of a noradrenergic clonal line of rat adrenal pheochromocytoma cells which respond to nerve growth factor. Proc. Natl. Acad. Sci. USA 1976, 73, 2424-2428. [CrossRef] [PubMed]

16. Mutoh, T.; Tokuda, A.; Miyadai, T.; Hamaguchi, M.; Fujiki, N. Ganglioside GM1 binds to the Trk protein and regulates receptor function. Proc. Natl. Acad. Sci. USA 1995, 92, 5087-15091. [CrossRef]

17. Nishio, M.; Fukumoto, S.; Furukawa, K.; Ichimura, A.; Miyazaki, H.; Kusunoki, S.; Urano, T.; Furukawa, K. Overexpressed GM1 suppresses nerve growth factor (NGF) signals by modulating the intracellular localization of NGF receptors and membrane fluidity in PC12 cells. J. Biol. Chem. 2004, 279, 33368-33378. [CrossRef]

18. Fukumoto, S.; Mutoh, T.; Hasegawa, T.; Miyazaki, H.; Okada, M.; Goto, G.; Furukawa, K.; Urano, T.; Furukawa, K. GD3 synthase gene expression in PC12 cells results in the continuous activation of TrkA and ERK1/2 and enhanced proliferation. J. Biol. Chem. 2000, 275, 5832-5838. [CrossRef]

19. Hamamura, K.; Furukawa, K.; Hayashi, T.; Hattori, T.; Nakano, J.; Nakashima, H.; Okuda, T.; Mizutani, H.; Hattori, H.; Ueda, M.; et al. Ganglioside GD3 promotes cell growth and invasion through p130Cas and paxillin in malignant melanoma cells. Proc. Natl. Acad. Sci. USA 2005, 102, 11041-11046. [CrossRef]

20. Dong, Y.; Ikeda, K.; Hamamura, K.; Zhang, Q.; Kondo, Y.; Matsumoto, Y.; Ohmi, Y.; Yamauchi, Y.; Furukawa, K.; Taguchi, R.; et al. GM1/GD1b/GA1 synthase expression results in the reduced cancer phenotypes with modulation of composition and raft-localization of gangliosides in a melanoma cell line. Cancer Sci. 2010, 101, 2039-2047. [CrossRef]

21. Handa, K.; Hakomori, S.I. Changes of glycoconjugate expression profiles during early development. Glycoconj. J. 2017, 34, 693-699. [CrossRef] [PubMed]

22. Furukawa, K.; Ohmi, Y.; Ji, S.; Zhang, P.; Bhuiyan, R.H.; Ohkawa, Y.; Tajima, O.; Hashimoto, N.; Furukawa, K. Glycolipids: Essential regulator of neuro- inflammation, metabolism and gliomagenesis. Biochim. Biophys. Acta Gen. Subj. 2017, 1861, 2479-2484. [CrossRef]

23. Ohsawa, T. Changes of mouse brain gangliosides during aging from young adult until senescence. Mech. Ageing Dev. 1989, 50, 169-177. [CrossRef]

24. Hilbig, R.; Lauke, G.; Rahmann, H. Brain gangliosides during the life span (embryogenesis to senescence) of the rat. Dev. Neurosci. 1983, 6, 260-270. [CrossRef] [PubMed]

25. Yu, R.K.; Nakatani, Y.; Yanagisawa, M. The role of glycosphingolipid metabolism in the developing brain. J. Lipid Res. 2009, 50, S440-S445. [CrossRef] [PubMed]

26. Segler-Stahl, K.; Webster, J.C.; Brunngraber, E.G. Changes in the concentration and composition of human brain gangliosides with aging. Gerontology 1983, 29, 161-168. [CrossRef]

27. Svennerholm, L.; Boström, K.; Helander, C.G.; Jungbjer, B. Membrane lipids in the aging human brain. J. Neurochem. 1991, 56, 2051-2059. [CrossRef]

28. Svennerholm, L.; Boström, K.; Jungbjer, B.; Olsson, L. Membrane lipids of adult human brain: Lipid composition of frontal and temporal lobe in subjects of age 20 to 100 years. J. Neurochem. 1994, 63, 1802-1811. [CrossRef]

29. Sarbu, M.; Dehelean, L.; Munteanu, C.V.A.; Vukelić, Ž.; Zamfir, A.D. Assessment of ganglioside age-related and topographic specificity in human brain by Orbitrap mass spectrometry. Anal. Biochem. 2017, 521, 40-54. [CrossRef]

30. Rogers, J.; Cooper, N.R.; Webster, S.; Schultz, J.; McGeer, P.L.; Styren, S.D.; Civin, W.H.; Brachova, L.; Bradt, B.; Ward, P. Complement activation by beta-amyloid in Alzheimer disease. Proc. Natl. Acad. Sci. USA 1992, 89, 10016-10020. [CrossRef]

31. Shen, Y.; Lue, L.; Yang, L.; Loher, A.; Kuo, Y.; Strohmeyer, R.; Goux, W.J.; Lee, V.; Johnson, G.V.; Webster, S.D.; et al. Complement activation by neurofibrillary tangles in Alzheimer's disease. Neurosci. Lett. 2001, 305, 165-168. [CrossRef] 
32. Hoarau, J.J.; Krejbich-Trotot, P.; Jaffar-Bandjee, M.C.; Das, T.; Thon-Hon, G.V.; Kumar, S.; Neal, J.W.; Gasque, P. Activation and control of CNS innate immune responses in health and diseases: A balancing act finely tuned by neuroimmune regulators (NIReg). CNS Neurol. Disord. Drug Targets 2011, 10, 25-43. [CrossRef] [PubMed]

33. Shen, Y.; Halperin, J.A.; Benzaquen, L.; Lee, C.M. Characterization of neuronal cell death induced by complement activation. Brain Res. Brain Res. Protoc. 1997, 1, 186-194. [CrossRef]

34. Terai, K.; Walker, D.G.; McGeer, E.G.; McGeer, P.L. Neurons express proteins of the classical complement pathway in Alzheimer disease. Brain Res. 1997, 769, 385-390. [CrossRef]

35. Yasojima, K.; Schwab, C.; McGeer, E.G.; McGeer, P.L. Up-regulated production and activation of the complement system in Alzheimer's disease brain. Am. J. Pathol. 1999, 154, 927-936. [CrossRef]

36. Jennemann, R.; Sandhoff, R.; Wang, S.; Kiss, E.; Gretz, N.; Zuliani, C.; Martin-Villalba, A.; Jäger, R.; Schorle, H.; Kenzelmann, N.; et al. Cell-specific deletion of glucosyl- ceramide synthase in brain leads to severe neural defects after birth. Proc. Natl. Acad. Sci. USA 2005, 102, 12459-12464. [CrossRef]

37. Tenner, A.J. Complement in Alzheimer's disease: Opportunities for modulating protective and pathogenic events. Neurobiol. Aging 2001, 22, 849-861. [CrossRef]

38. Stevens, B.; Allen, N.J.; Vazquez, L.E.; Howell, G.R.; Christopherson, K.R.; Nouri, N.; Micheva, K.D.; Mehalow, A.K.; Huberman, A.D.; Stafford, B.; et al. The classical complement cascade mediates CNS synapse elimination. Cell 2007, 131, 1164-1178. [CrossRef]

39. Wyss-Coray, T.; Yan, F.; Lin, A.H.; Lambris, J.D.; Alexander, J.J.; Quigg, R.J.; Masliah, E. Prominent neurodegeneration and increased plaque formation in complement-inhibited Alzheimer's mice. Proc. Natl. Acad. Sci. USA 2002, 99, 10837-10842. [CrossRef]

40. Yanagisawa, K. GM1 ganglioside and Alzheimer's disease. Glycoconj. J. 2015, 32, 87-91. [CrossRef]

41. Matsuzaki, K.; Kato, K.; Yanagisawa, K. A beta polymerization through interaction with membrane gangliosides. Biochim. Biophys. Acta 2010, 1801, 868-877. [CrossRef] [PubMed]

42. Bernardo, A.; Harrison, F.E.; McCord, M.; Zhao, J.; Bruchey, A.; Davies, S.S.; Roberts, L.J., 2nd; Mathews, P.M.; Matsuoka, Y.; Ariga, T.; et al. Elimination of GD3 synthase improves memory and reduces amyloid-beta plaque load in transgenic mice. Neurobiol. Aging 2009, 30, 1777-1791. [CrossRef] [PubMed]

43. Oikawa, N.; Yamaguchi, H.; Ogino, K.; Taki, T.; Yuyama, K.; Yamamoto, N.; Shin, R.W.; Furukawa, K.; Yanagisawa, K. Gangliosides determine the amyloid pathology of Alzheimer's disease. Neuroreport 2009, 20, 1043-1046.

44. Yamaguchi, T.; Yamauchi, Y.; Furukawa, K.; Ohmi, Y.; Ohkawa, Y.; Zhang, Q.; Okajima, T.; Furukawa, K. Expression of B4GALNT1, an essential glycosyltransferase for the synthesis of complex gangliosides, suppresses BACE1 degradation and modulates APP processing. Sci. Rep. 2016, 6, 34505. [CrossRef] [PubMed]

45. Barrier, L.; Ingrand, S.; Damjanac, M.; Bilan, A.R.; Hugon, J.; Page, G. Genotype-related changes of ganglioside composition in brain regions of transgenic mouse models of Alzheimer's disease. Neurobiol. Aging 2007, 28, 1863-1872. [CrossRef] [PubMed]

46. Schneider, J.S. Gangliosides and glycolipids in neurodegenerative disorders. Adv. Neurobiol. 2014, 9, 449-461. [CrossRef]

47. Takamiya, K.; Yamamoto, A.; Furukawa, K.; Yamashiro, S.; Shin, M.; Okada, M.; Fukumoto, S.; Haraguchi, M.; Takeda, N.; Fujimura, K.; et al. Mice with disrupted GM2/GD2 synthase gene lack complex gangliosides but exhibit only subtle defects in their nervous system. Proc. Natl. Acad. Sci. USA 1996, 93, 10662-10667. [CrossRef]

48. Wu, G.; Lu, Z.H.; Kulkarni, N.; Ledeen, R.W. Deficiency of ganglioside GM1 correlates with Parkinson's disease in mice and humans. J. Neurosci. Res. 2012, 90, 1997-2008. [CrossRef]

49. Schneider, J.S.; Pope, A.; Simpson, K.; Taggart, J.; Smith, M.G.; DiStefano, L. Recovery from experimental parkinsonism in primates with GM1 ganglioside treatment. Science 1992, 256, 843-846. [CrossRef]

50. Schneider, J.S.; Gollomp, S.M.; Sendek, S.; Colcher, A.; Cambi, F.; Du, W. A randomized, controlled, delayed start trial of GM1 ganglioside in treated Parkinson's disease patients. J. Neurol. Sci. 2013, 324, 140-148. [CrossRef]

51. Okada, M.; Itoh, M.; Haraguchi, M.; Okajima, T.; Inoue, M.; Oishi, H.; Matsuda, Y.; Iwamoto, T.; Kawano, T.; Fukumoto, S.; et al. b-series Ganglioside deficiency exhibits no definite changes in the neurogenesis and the sensitivity to Fas-mediated apoptosis but impairs regeneration of the lesioned hypoglossal nerve. J. Biol. Chem. 2002, 277, 1633-1636. [CrossRef] 
52. Akkhawattanangkul, Y.; Maiti, P.; Xue, Y.; Aryal, D.; Wetsel, W.C.; Hamilton, D.; Fowler, S.C.; McDonald, M.P. Targeted deletion of GD3 synthase protects against MPTP-induced neurodegeneration. Genes Brain Behav. 2017, 16, 522-536. [CrossRef] [PubMed]

53. Furukawa, K.; Ohmi, Y.; Kondo, Y.; Ohkawa, Y.; Tajima, O.; Furukawa, K. Regulatory function of glycosphingolipids in the inflammation and degeneration. Arch. Biochem. Biophys. 2015, 571, 58-65. [CrossRef] [PubMed]

54. Sela, B.A.; Offner, H.; Konat, G.; Lev-Ram, J.; Cohen, O.; Cohen, I.R. Immunological expression of gangliosides in multiple sclerosis and in a demyelinating model disease in rabbits. Adv. Exp. Med. Biol. 1984, 174, 441-453. [PubMed]

55. Pilkington, G.J.; Dunan, J.R.; Rogers, J.P.; Clarke, T.M.; Knott, J.C. Growth factor modulation of surface ganglioside expression in cloned neoplastic glia. Neurosci. Lett. 1993, 149, 1-5. [CrossRef]

56. Kawai, K.; Kuroda, S.; Watarai, S.; Takahashi, H.; Ikuta, F. Occurrence of GD3 ganglioside in reactive astrocytes-an immunocytochemical study in the ratbrain. Neurosci. Lett. 1994, 174, 225-227. [CrossRef]

57. Welte, K.; Miller, G.; Chapman, P.B.; Yuasa, H.; Natoli, E.; Kunicka, J.E.; Cordon-Cardo, C.; Buhrer, C.; Old, L.J.; Houghton, A.N. Stimulation of T lymphocyte proliferation by monoclonal antibodies against GD3ganglioside. J. Immunol. 1987, 139, 1763-1771.

58. Yamashiro, S.; Okada, M.; Haraguchi, M.; Furukawa, K.; Lloyd, K.O.; Shiku, H.; Furukawa, K. Expression of alpha 2,8-sialyltransferase (GD3 synthase) gene in human cancer cell lines: High level expression in melanomas and up-regulation in activated T lymphocytes. Glycoconj. J. 1995, 12, 894-900. [CrossRef]

59. Yoshimura, A.; Takamiya, K.; Kato, I.; Nakaya, E.; Shiku, H.; Furukawa, K. GD2 ganglioside-specific monoclonal antibody reacts with murine cytotoxic T lymphocytes reactive with FBL-3N erythroleukaemia. Scand. J. Immunol. 1994, 40, 557-563. [CrossRef]

60. Furukawa, K.; Akagi, T.; Nagata, Y.; Yamada, Y.; Shimotohno, K.; Cheung, N.K.; Shiku, H.; Furukawa, K. GD2 ganglioside on human T-lymphotropic virus type I-infected T cells: Possible activation of beta-1,4-N-acetylgalactosaminyl- transferase gene by p40tax. Proc. Natl. Acad. Sci. USA 1993, 90, 1972-1976. [CrossRef]

61. Okada, M.; Furukawa, K.; Yamashiro, S.; Yamada, Y.; Haraguchi, M.; Horibe, K.; Kato, K.; Tsuji, Y.; Furukawa, K. High expression of ganglioside alpha-2,8-sialyl- transferase (GD3 synthase) gene in adult T-cell leukemia cells unrelated to the gene expression of human T-lymphotropic virus type I. Cancer Res. 1996, 56, 2844-2848. [PubMed]

62. Villanueva-Cabello, T.M.; Mollicone, R.; Cruz-Muñoz, M.E.; López-Guerrero, D.V.; Martínez-Duncker, I. Activation of human naïve Th cells increases surface expression of GD3 and induces neoexpression of GD2 that colocalize with TCR clusters. Glycobiology 2015, 25, 1454-1464. [CrossRef] [PubMed]

63. Nagata, Y.; Yamashiro, S.; Yodoi, J.; Loyd, K.O.; Shiku, H.; Furukawa, K. Expression cloning of beta 1,4 $\mathrm{N}$-acetylgalactosaminyltransferase cDNAs that determine the expression of GM2 and GD2 gangliosides. J. Biol. Chem. 1992, 267, 12082-12089. [PubMed]

64. Haraguchi, M.; Yamashiro, S.; Yamamoto, A.; Furukawa, K.; Takamiya, K.; Lloyd, K.O.; Shiku, H.; Furukawa, K. Isolation of GD3 synthase gene by expression cloning of GM3 alpha-2,8-sialyltransferase cDNA using anti-GD2 monoclonal antibody. Proc. Natl. Acad. Sci. USA 1994, 91, 10455-10459. [CrossRef]

65. Nara, K.; Watanabe, Y.; Maruyama, K.; Kasahara, K.; Nagai, Y.; Sanai, Y. Expression cloning of a CMP-NeuAc:NeuAc alpha 2-3Gal beta 1-4Glc beta 1-1'Cer alpha 2,8-sialyltransferase (GD3 synthase) from human melanoma cells. Proc. Natl. Acad. Sci. USA 1994, 91, 7952-7956. [CrossRef]

66. Sasaki, K.; Kurata, K.; Kojima, N.; Kurosawa, N.; Ohta, S.; Hanai, N.; Tsuji, S.; Nishi, T. Expression cloning of a GM3-specific alpha-2,8-sialyltransferase (GD3synthase). J. Biol. Chem. 1994, 269, 15950-15956. [PubMed]

67. Miyazaki, H.; Fukumoto, S.; Okada, M.; Hasegawa, T.; Furukawa, K. Expression cloning of rat cDNA encoding UDP-galactose: GD2 beta1,3-galactosyltransferase that determines the expression of GD1b/GM1/GA1. J. Biol. Chem. 1997, 272, 24794-24799. [CrossRef]

68. Fukumoto, S.; Miyazaki, H.; Goto, G.; Urano, T.; Furukawa, K.; Furukawa, K. Expression cloning of mouse cDNA of CMP-NeuAc: Lactosylceramide alpha2,3-sialyltransferase, an enzyme that initiates the synthesis of gangliosides. J. Biol. Chem. 1999, 274, 9271-9276. [CrossRef]

69. Kono, M.; Takashima, S.; Liu, H.; Inoue, M.; Kojima, N.; Lee, Y.C.; Hamamoto, T.; Tsuji, S. Molecular cloning and functional expression of a fifth-type alpha2,3-sialyltransferase (mST3Gal V: GM3 synthase). Biochem. Biophys. Res. Commun. 1998, 253, 170-175. [CrossRef] 
70. Ishii, A.; Ohta, M.; Watanabe, Y.; Matsuda, K.; Ishiyama, K.; Sakoe, K.; Nakamura, M.; Inokuchi, J.; Sanai, Y.; Saito, M. Expression cloning and functional characterization of human cDNA for ganglioside GM3 synthase. J. Biol. Chem. 1998, 273, 31652-31655. [CrossRef]

71. Kojima, Y.; Fukumoto, S.; Furukawa, K.; Okajima, T.; Wiels, J.; Yokoyama, K.; Suzuki, Y.; Urano, T.; Ohta, M.; Furukawa, K. Molecular cloning of globotriaosyl- ceramide/CD77 synthase, a glycosyltransferase that initiates the synthesis of globo series glycosphingolipids. J. Biol. Chem. 2000, 275, 15152-15156. [CrossRef] [PubMed]

72. Steffensen, R.; Carlier, K.; Wiels, J.; Levery, S.B.; Stroud, M.; Cedergren, B.; Nilsson Sojka, B.; Bennett, E.P.; Jersild, C.; Clausen, H. Cloning and expression of the histo-blood group Pk UDP-galactose: Ga1beta-4G1cbeta1-cer alpha1,4-galactosyltransferase. Molecular genetic basis of the p phenotype. J. Biol. Chem. 2000, 275, 16723-16729. [CrossRef] [PubMed]

73. Keusch, J.J.; Manzella, S.M.; Nyame, K.A.; Cummings, R.D.; Baenziger, J.U. Cloning of Gb3 synthase, the key enzyme in globo-series glycosphingolipid synthesis, predicts a family of alpha1,4-glycosyltransferases conserved in plants, insects, and mammals. J. Biol. Chem. 2000, 275, 25315-25321. [CrossRef] [PubMed]

74. Okuda, T.; Tokuda, N.; Numata, S.; Ito, M.; Ohta, M.; Kawamura, K.; Wiels, J.; Urano, T.; Tajima, O.; Furukawa, K.; et al. Targeted disruption of Gb3/CD77 synthase gene resulted in the complete deletion of globo-series glycosphingolipids and loss of sensitivity to verotoxins. J. Biol. Chem. 2006, 281, 10230-10235. [CrossRef]

75. Nishie, T.; Hikimochi, Y.; Zama, K.; Fukusumi, Y.; Ito, M.; Yokoyama, H.; Naruse, C.; Ito, M.; Asano, M. Beta4-galactosyltransferase-5 is a lactosylceramide synthase essential for mouse extra-embryonic development. Glycobiology 2010, 20, 1311-1322. [CrossRef]

76. Tokuda, N.; Numata, S.; Li, X.; Nomura, T.; Takizawa, M.; Kondo, Y.; Yamashita, Y.; Hashimoto, N.; Kiyono, T.; Urano, T. $\beta 4 \mathrm{GalT6}$ is involved in the synthesis of lactosylceramide with less intensity than $\beta 4$ GalT5. Glycobiology 2013, 23, 1175-1183. [CrossRef]

77. Inoue, M.; Fujii, Y.; Furukawa, K.; Okada, M.; Okumura, K.; Hayakawa, T.; Furukawa, K.; Sugiura, Y. Refractory skin injury in the complex knock-out mice expressing only GM3 ganglioside. J. Biol. Chem. 2002, 277, 29881-29888. [CrossRef]

78. Tajima, O.; Egashira, N.; Ohmi, Y.; Fukue, Y.; Mishima, K.; Iwasaki, K.; Fujiwara, M.; Inokuchi, J.; Sugiura, Y.; Furukawa, K.; et al. Reduced motor and sensory functions and emotional response in GM3-only mice: Emergence from early stage of life and exacerbation with aging. Behav. Brain Res. 2009, 198, 74-82. [CrossRef]

79. Yoshihara, T.; Satake, H.; Nishie, T.; Okino, N.; Hatta, T.; Otani, H.; Naruse, C.; Suzuki, H.; Sugihara, K.; Kamimura, E.; et al. Lactosylceramide synthases encoded by B4galt 5 and 6 genes are pivotal for neuronal generation and myelin formation in mice. PLoS Genet. 2018, 14, e1007545. [CrossRef]

80. Ohmi, Y.; Tajima, O.; Ohkawa, Y.; Mori, A.; Sugiura, Y.; Furukawa, K.; Furukawa, K. Gangliosides play pivotal roles in the regulation of complement systems and in the maintenance of integrity in nerve tissues. Proc. Natl. Acad. Sci. USA 2009, 106, 22405-22410. [CrossRef]

81. Ohmi, Y.; Tajima, O.; Ohkawa, Y.; Yamauchi, Y.; Sugiura, Y.; Furukawa, K.; Furukawa, K. Gangliosides are essential in the protection of inflammation and neurodegeneration via maintenance of lipid rafts: Elucidation by a series of ganglioside-deficient mutant mice. J. Neurochem. 2011, 116, 926-935. [CrossRef] [PubMed]

82. Palmano, K.; Rowan, A.; Guillermo, R.; Guan, J.; McJarrow, P. The role of gangliosides in neurodevelopment. Nutrients 2015, 7, 3891-3913. [CrossRef] [PubMed]

83. Furukawa, K.; Ohmi, Y.; Ohkawa, Y.; Tokuda, N.; Kondo, Y.; Tajima, O.; Furukawa, K. Regulatory mechanisms of nervous systems with glycosphingolipids. Neurochem. Res. 2011, 36, 1578-1586. [CrossRef] [PubMed]

84. Sugiura, Y.; Furukawa, K.; Tajima, O.; Mii, S.; Honda, T.; Furukawa, K. Sensory nerve-dominant nerve degeneration and remodeling in the mutant mice lacking complex gangliosides. Neuroscience 2005, 135, 1167-1178. [CrossRef]

85. Sheikh, K.A.; Sun, J.; Liu, Y.; Kawai, H.; Crawford, T.O.; Proia, R.L.; Griffin, J.W.; Schnaar, R.L. Mice lacking complex gangliosides develop Wallerian degeneration and myelination defects. Proc. Natl. Acad. Sci. USA 1999, 96, 7532-7537. [CrossRef]

86. Kawai, H.; Allende, M.L.; Wada, R.; Kono, M.; Sango, K.; Deng, C.; Miyakawa, T.; Crawley, J.N.; Werth, N.; Bierfreund, U.; et al. Mice expressing only monosialoganglioside GM3 exhibit lethal audiogenic seizures. J. Biol. Chem. 2001, 276, 6885-6888. [CrossRef] 
87. Ichikawa, S.; Sakiyama, H.; Suzuki, G.; Hidari, K.I.; Hirabayashi, Y. Expression cloning of a cDNA for human ceramide glucoseyltransferase that catalyze the first glycosylation step of glycosphingolipid synthesis. Proc. Natl. Acad. Sci. USA 1996, 93, 4638-4643. [CrossRef]

88. Yamashita, T.; Wada, R.; Sasaki, T.; Deng, C.; Bierfreund, U.; Sandoff, K.; Proia, R.L. A vital role for glycosphingolipid synthesis during development and differentiation. Proc. Natl. Acad. Sci. USA 1999, 96, 9142-9147. [CrossRef]

89. Ohmi, Y.; Ohkawa, Y.; Tajima, O.; Sugiura, Y.; Furukawa, K.; Furukawa, K. Ganglioside deficiency causes inflammation and neurodegeneration via the activation of complement system in the spinal cord. J. Neuroinflammation 2014, 11, 61. [CrossRef]

90. McGonigal, R.; Rowan, E.G.; Greenshields, K.N.; Halstead, S.K.; Humphreys, P.D.; Rother, R.P.; Furukawa, K.; Willison, H.J. Anti-GD1a antibodies activate complement and calpain to injure distal motor nodes of Ranvier in mice. Brain 2010, 133, 1944-1960. [CrossRef]

91. McGonigal, R.; Cunningham, M.E.; Yao, D.; Barrie, J.D.; Sankaranarayanan, S.; Fewou, S.N.; Furukawa, K.; Yednock, T.; Willison, H.J. C1q-targeted inhibition of the classical complement pathway prevents injury in a novel mouse model of acute motor axonal neuropathy. Acta Neuropathol. Commun. 2016, 4, 23. [CrossRef] [PubMed]

92. Halstead, S.K.; Zitman, F.M.; Humphreys, P.D.; Greenshields, K.; Versschuuren, J.J.; Jacobs, B.C.; Rother, R.P.; Promp, J.J.; Willison, H.J. Eculizumab prevents anti-ganglioside antibody-mediated neuropathy in a murine model. Brain 2008, 131, 1197-1208. [CrossRef]

93. Davidson, A.I.; Halstead, S.K.; Goodfellow, J.A.; Chavada, G.; Mallik, A.; Overell, J.; Lunn, M.P.; MaConnachie, A.; van Doorn, P.; Willison, H.J. Inhibition of complement in Guillain-Barré syndrome: The ICA-GBS study. J. Peripher. Nerv. Syst. 2017, 22, 4-12. [CrossRef]

94. Furukawa, K.; Ohmi, Y.; Ohkawa, Y.; Hashimoto, N.; Kondo, Y.; Tajima, O.; Furukawa, K. Roles of glycosphingolipids in the regulation of the membrane organization and cell signaling in lipid rafts. In Membrane Organization and Lipid Rafts in the Cell and Artificial Membranes; Catala, A., Ed.; Nova Science Publishers: London, UK, 2016; pp. 129-146.

95. Simons, K.; Ikonen, E. Functional rafts in cell membranes. Nature 1997, 387, 569-572. [CrossRef]

96. Hamamura, K.; Tsuji, M.; Hotta, H.; Ohkawa, Y.; Takahashi, M.; Shibuya, H.; Nakashima, H.; Yammauchi, Y.; Hashimoto, N.; Hattori, H.; et al. Functional activation of Src family kinase yes protein is essential for the enhanced malignant properties of human melanoma cells expressing ganglioside GD3. J. Biol. Chem. 2011, 286, 18526-18537. [CrossRef] [PubMed]

97. Ohkawa, Y.; Miyazaki, S.; Hamamura, K.; Kambe, M.; Miyata, M.; Tajima, O.; Ohmi, Y.; Yamauchi, Y.; Furukawa, K.; Furukawa, K. Ganglioside GD3 enhances adhesion signals and augments malignant properties of melanoma cells by recruiting integrins to glycolipid-enriched microdomains. J. Biol. Chem. 2010, 285, 27213-27223. [CrossRef] [PubMed]

98. Kotani, N.; Gu, J.; Isaji, T.; Udaka, K.; Taniguchi, N.; Honke, K. Biochemical visualization of cell surface molecular clustering in living cells. Proc. Natl. Acad. Sci. USA 2008, 105, 7405-7409. [CrossRef]

99. Todeschini, A.R.; Hakomori, S.I. Functional role of glycosphingolipids and gangliosides in control of cell adhesion, motility, and growth, through glycosynaptic microdomains. Biochim. Biophys. Acta 2008, 1780, 421-433. [CrossRef]

100. Simons, K.; Gerl, M.J. Revitalizing membrane rafts: New tools and insights. Nat. Rev. Mol. Cell Biol. 2010, 11, 688-699. [CrossRef]

101. Nakashima, H.; Hamamura, K.; Houjou, T.; Taguchi, R.; Yamamoto, N.; Mitsudo, K.; Tohnai, I.; Ueda, M.; Urano, T.; Furukawa, K.; et al. Overexpression of caveolin-1 in a human melanoma cell line results in dispersion of ganglioside GD3 from lipid rafts and alteration of leading edges, leading to attenuation of malignant properties. Cancer Sci. 2007, 98, 512-520. [CrossRef]

102. Fujita, A.; Cheng, J.; Hirakawa, M.; Furukawa, K.; Kusunoki, S.; Fujimoto, T. Gangliosides GM1 and GM3 in the living cell membrane form clusters susceptible to cholesterol depletion and chilling. Mol. Biol. Cell 2007, 18, 2112-2122. [CrossRef] [PubMed]

103. Ohmi, Y.; Ohkawa, Y.; Yamauchi, Y.; Tajima, O.; Furukawa, K.; Furukawa, K. Essential roles of gangliosides in the formation and maintenance of membrane microdomains in brain tissues. Neurochem. Res. 2012, 37, 1185-1191. [CrossRef] 
104. Yang, L.B.; Li, R.; Meri, S.; Rogers, J.; Shen, Y. Deficiency of complement defense protein CD59 may contribute to neurodegeneration in Alzheimer's disease. J. Neurosci. 2000, 20, 7505-7509. [CrossRef] [PubMed]

105. Mason, J.C.; Yarwood, H.; Sugars, K.; Morgan, B.P.; Davies, K.A.; Haskard, K.A. Induction of decay-accelerating factor by cytokines or the membrane-attack complex protects vascular endothelial cells against complement deposition. Blood 1999, 94, 1673-1682. [CrossRef] [PubMed]

106. Zurzolo, C.; Simons, K. Glycosylphosphatidylinositol-anchored proteins: Membrane organization and transport. Biochim. Biophys. Acta 2016, 1858, 632-639. [CrossRef] [PubMed]

107. Simpson, M.A.; Cross, H.; Proukakis, C.; Priestman, D.A.; Neville, D.C.; Reinkensmeier, G.; Wang, H.; Wiznitzer, M.; Gurtz, K.; Verganelaki, A.; et al. Infantile-onset symptomatic epilepsy syndrome caused by a homozygous loss-of-function mutation of GM3 synthase. Nat. Genet. 2004, 36, 1225-1229. [CrossRef] [PubMed]

108. Boccuto, L.; Aoki, K.; Flanagan-Steet, H.; Chen, C.F.; Fan, X.; Bartel, F.; Petukh, M.; Pittman, A.; Saul, R.; Chaubey, A.; et al. A mutation in a ganglioside biosynthetic enzyme, ST3GAL5, results in salt \& pepper syndrome, a neurocutaneous disorder with altered glycolipid and glycoprotein glycosylation. Hum. Mol. Genet. 2014, 23, 418-433. [PubMed]

109. Wang, H.; Bright, A.; Xin, B.; Bockoven, J.R.; Paller, A.S. Cutaneous dyspigmentation in patients with ganglioside GM3 synthase deficiency. Am. J. Med. Genet. A 2013, 161, 875-879. [CrossRef]

110. Yoshikawa, M.; Go, S.; Suzuki, S.; Suzuki, A.; Katori, Y.; Morlet, T.; Gottlieb, S.M.; Fujiwara, M.; Iwasaki, K.; Strauss, K.A.; et al. Ganglioside GM3 is essential for the structural integrity and function of cochlear hair cells. Hum. Mol. Genet. 2015, 24, 2796-2807. [CrossRef]

111. Boukhris, A.; Schule, R.; Loureiro, J.L.; Lourenço, C.M.; Mundwiller, E.; Gonzalez, M.A.; Charles, P.; Gauthier, J.; Rekik, I.; Acosta Lebrigio, R.F.; et al. Alteration of ganglioside biosynthesis responsible for complex hereditary spastic paraplegia. Am. J. Hum. Genet. 2013, 93, 118-123. [CrossRef]

112. Harlalka, G.V.; Lehman, A.; Chioza, B.; Baple, E.L.; Maroofian, R.; Cross, H.; Sreekantan-Nair, A.; Priestman, D.A.; Al-Turki, S.; McEntagart, M.E.; et al. Mutations in B4GALNT1 (GM2 synthase) underlie a new disorder of ganglioside biosynthesis. Brain 2013, 136, 3618-3624. [CrossRef] [PubMed]

113. Wakil, S.M.; Monies, D.M.; Ramzan, K.; Hagos, S.; Bastaki, L.; Meyer, B.F.; Bohlega, S. Novel B4GALNT1 mutations in a complicated form of hereditary spastic paraplegia. Clin. Genet. 2014, 86, 500-501. [CrossRef] [PubMed]

114. Bhuiyan, R.H.; Ohmi, Y.; Ohkawa, Y.; Zhang, P.; Takano, M.; Hashimoto, N.; Okajima, T.; Furukawa, K.; Furukawa, K. Loss of enzyme activity in mutated B4GALNT1 gene products found in patients with hereditary spastic paraplegia resulted in relatively mild neurological disorders: Similarity with phenotypes of B4galnt1 knockout mice. Neuroscience 2018, 397, 94-106. [CrossRef]

115. Takamiya, K.; Yamamoto, A.; Furukawa, K.; Zhao, J.; Fukumoto, S.; Yamashiro, S.; Okada, M.; Haraguchi, M.; Shin, M.; Kishikawa, M.; et al. Complex gangliosides are essential in spermatogenesis of mice: Possible roles in the transport of testosterone. Proc. Natl. Acad. Sci. USA 1998, 95, 12147-12152. [CrossRef] [PubMed]

116. Kitajima, K.; Varki, N.; Sato, C. Advanced Technologies in Sialic Acid and Sialoglycoconjugate Analysis. Top. Curr. Chem. 2015, 367, 75-103. [PubMed]

117. Cavdarli, S.; Dewald, J.H.; Yamakawa, N.; Guérardel, Y.; Terme, M.; Le Doussal, J.M.; Delannoy, P.; Groux-Degroote, S. Identification of 9-O-acetyl-N-acetyl-neuraminic acid (Neu5,9Ac2) as main O-acetylated sialic acid species of GD2 in breast cancer cells. Glycoconj. J. 2019, 36, 79-90. [CrossRef]

118. Nakayama, H.; Nagafuku, M.; Suzuki, A.; Iwabuchi, K.; Inokuchi, J.I. The regulatory roles of glycosphingolipid-enriched lipid rafts in immune systems. FEBS Lett. 2018, 592, 3921-3942. [CrossRef]

119. Kondo, Y.; Ikeda, K.; Tokuda, N.; Nishitani, C.; Ohto, U.; Akashi, T.S.; Ito, Y.; Uchikawa, M.; Kuroki, Y.; Taguchi, R.; et al. TLR4-MD-2 complex is negatively regulated by an endogenous ligand, globotetraosylceramide. Proc. Natl. Acad. Sci. USA 2013, 110, 4714-4719. [CrossRef]

120. Hashimoto, N.; Ito, S.; Tsuchida, A.; Bhuiyan, R.H.; Okajima, T.; Yamamoto, A.; Furukawa, K.; Ohmi, Y.; Furukawa, K. The ceramide moiety of disialoganglioside (GD3) is essential for GD3 recognition by the sialic acid-binding lectin SIGLEC7 on the cell surface. J. Biol. Chem. 2019, 294, 10833-10845. [CrossRef]

121. Yao, D.; McGonigal, R.; Barrie, J.A.; Cappell, J.; Cunningham, M.E.; Meehan, G.R.; Fewou, S.N.; Edgar, J.M.; Rowan, E.; Ohmi, Y.; et al. Neuronal expression of GalNAc transferase is sufficient to prevent the age-related neurodegenerative phenotype of complex ganglioside deficient mice. J. Neurosci. 2014, 34, 880-891. [CrossRef] 
122. Komura, N.; Suzuki, K.G.; Ando, H.; Konishi, M.; Koikeda, M.; Imamura, A.; Chadda, R.; Fujiwara, T.K.; Tsuboi, H.; Sheng, R.; et al. Ultra-high-resolution imaging of gangliosides in GEM/rafts Raft-based interactions of gangliosides with a GPI-anchored receptor. Nat. Chem. Biol. 2016, 12, 402-410. [CrossRef] [PubMed]

123. Lingwood, D.; Simons, K. Lipid rafts as a membrane-organizing principle. Science 2010, 327, 46-50. [CrossRef] [PubMed]

(C) 2020 by the authors. Licensee MDPI, Basel, Switzerland. This article is an open access article distributed under the terms and conditions of the Creative Commons Attribution (CC BY) license (http://creativecommons.org/licenses/by/4.0/). 